\title{
Bioprospektif Perairan Berdasarkan Produktivitas: Studi Kasus Estuari Sungai Serayu Cilacap, Indonesia
}

\author{
Nur Laila Rahayu ${ }^{1}$, W.Lestari ${ }^{1}$ Dan Erwin Riyanto Ardly ${ }^{1}$ \\ ${ }^{1}$ Fakultas Biologi, Universitas Jenderal Soedirman \\ Email : nurlailarahayu@gmail.com.
}

\begin{abstract}
The land use changes of Serayu River resulted on high sedimentation and accumulation of materials in downstream. This phenomena will lead to decreasing of primary and secondary productivities. The purposes of the research were to describe bio prospective of estuary based on primary and secondary productivities. Survey with purposive sampling technique was applied on this research. Estuary Serayu River was divided into five sites based on salinity. The nearest sea (Site 1) with $26 \%$ and the furthest stations (Site 5) with $8 \%$. Sampling was conducted at high and low tide time on August until November 2016. The obtained data of richness and abundance plankton were analyzed descriptively and the correlation between environmental factors and plancton were calculated by PCA. The result shown that the abundance of phytoplankton was 4.106-28.875 ind. $\mathrm{L}^{-1}$, the primery productivity was $3,31-5,21$ mg.C. $\mathrm{m}^{-2} \cdot \mathrm{d}^{-1}$ and the abundance of zooplankton was 259-1036 ind. $\mathrm{L}^{-1}$ these indicated that estuary of Serayu possessed low prospective for fishery. The primary and secondary productivities in estuary serayu were positive correlated more to are penetration of solar, TSS and $\mathrm{pH}$.
\end{abstract}

Key Words : bioprospektive, estuary Serayu River, productivity

\begin{abstract}
Abstrak
Perubahan tata guna Sungai Serayu mengakibatkan peningkatan material sedimentasi ke badan perairan. Kekeruhannya akan terakumulasi pada daerah muara atau estuari yang akan berdampak pada biota terutama plankton sebagai produktivitas primer dan produktivitas sekunder. Penelitian ini dilakukan dengan menggunakan metode survey dan purposive sampling. Estuari Sungai Serayu dibagi menjadi 5 stasiun dimulai dari stasiun terdekat dengan laut (Stasiun 1) dengan salinitas $26 \%$ dan stasiun terjauh dari laut (Stasiun 5) dengan salinitas $8 \%$. Sampel air dan plankton diambil pada saat pasang tertinggi dan surut terendah pada Agustus hingga November 2016. Data yang diperoleh yaitu kekayaan dan kelimpahan plankton dianalisis secara deskriptif dan mengkaji pengaruh faktor lingkungan terhadap produktivitas primer dan sekunder menggunakan PCA. Berdasarkan hasil penelitian kelimpahan fitoplankton 4.106-28.875 ind. $\mathrm{L}^{-1}$, produktivitas primer perairan dalam bentuk karbon 3,31-5,21 mg.C.m ${ }^{-2} \cdot \mathrm{d}^{-1}$ dan kelimpahan zooplankton 259-1036 ind. $\mathrm{L}^{-1}$, indikator tersebut dinilai kurang prospek untuk perikanan. Faktor lingkungan yang memiliki hubungan posisitf terhadap produktivitas perairan estuari Sungai Serayu pada saat pasang tertinggi maupun surut terendah yaitu tingkat kecerahan, kandungan TSS, dan $\mathrm{pH}$.
\end{abstract}

Kata kunci : bioprospektif, estuari Sungai Serayu, produktivitas

\section{Pendahuluan}

Daerah Aliran Sungai (DAS) Serayu telah mengalami perubahan land use. Dibagian hulu sungai, telah terjadi perubahan lahan kritis hutan menjadi lahan pertanian. Hal ini berdampak pada laju erosi, sedimentasi dan kekeruhan seperti yang dilaporkan oleh Balai Pengelolaan Daerah Aliran Sungai (BPDAS) Serayu-Opak-Progo (2007), laju erosi Sungai Serayu mencapai lebih dari 180 ton.ha.tahun ${ }^{-1}$ yang diukur berdasarkan parameter penentu kekritisan lahan dari Departemen Kehutanan (SK Dirjen RRL No. 041/Kpts/V/1998). Konsekuensi dari laju erosi yang meningkat akan diikuti dengan sedimentasi dan kekeruhan yang meningkat khususnya di daerah estuari Sungai Serayu. Akumulasi material sedimentasi dikhawatirkan akan berdampak pada penurunan kualitas air seperti kandungan TSS yang meningkat dan akan mempengaruhi kekayaan dan kelimpahan plankton sebagai pakan alami ikan.

Bioprospektif perairan untuk perikanan dapat digambarkan dengan produktivitas primer dan sekunder. Laju produktivitas primer sangat dipengaruhi oleh cahaya matahari atau intensitas cahaya dan kandungan nutrien (Nontji, 2008). Hubungan antara produktivitas primer dan cahaya matahari dibuktikan oleh Alianto et al. (2008), yang memperoleh $\mathrm{r}=82$ dan produktivitas primer tertinggi diperoleh sebesar $34 \mathrm{mg} . \mathrm{C} \cdot \mathrm{m}^{-3} \cdot \mathrm{h}^{-1}$ di Teluk Banten. Afdal (2011) melaporkan produktivitas primer Sungai Donan mencapai $0,070 \mathrm{mg} \cdot \mathrm{C} \cdot \mathrm{m}^{-2} \cdot \mathrm{d}^{-1}$ di stasiun terdekat dengan laut pada kondisi temperatur $28,20{ }^{\circ} \mathrm{C}, \mathrm{pH} 7,91$ dan kandungan nutrien seperti kandungan fosfat 0,05 $\mu \mathrm{g} \cdot \mathrm{L}^{-1}$. Biomassa fitoplankton meningkat, diikuti dengan peningkatan biomassa zooplankton (Sverdrup et al., 2008).

Penelitian ini

bertujuan mengkaji bioprospektif perairan berdasarkan produktivitas primer dan sekunder dengan menggunakan data kekayaan dan kelimpahan plankton serta hubungan faktor lingkungan antara produktivitas perairan estuari Sungai Serayu Kabupaten Cilacap 


\section{Metode}

\section{Lokasi dan Waktu Penelitian}

Penelitian ini dilakukan dengan menggunakan metode survey dengan teknik pengambilan sampel dilakukan secara purpo sive sampling. Estuari Sungai Serayu dibagi menjadi 5 stasiun dimulai dari stasiun terdekat dengan laut (Stasiun 1) dengan salinitas $26 \%$ dan stasiun terjauh dari laut (Stasiun 5) dengan salinitas $8 \%$ stasiun tersebut bertepatan dengan stasiun pemantauan PDAM Kesugihan. Stasiun 1 sampai 5 dibagi menjadi 3 sub stasiun dengan jarak $\pm 2,5$ km (Gambar 1). Sampel air dan plankton diambil pada saat pasang tertinggi dan surut terendah setiap bulan pada bulan Agustus sampai dengan November 2016.

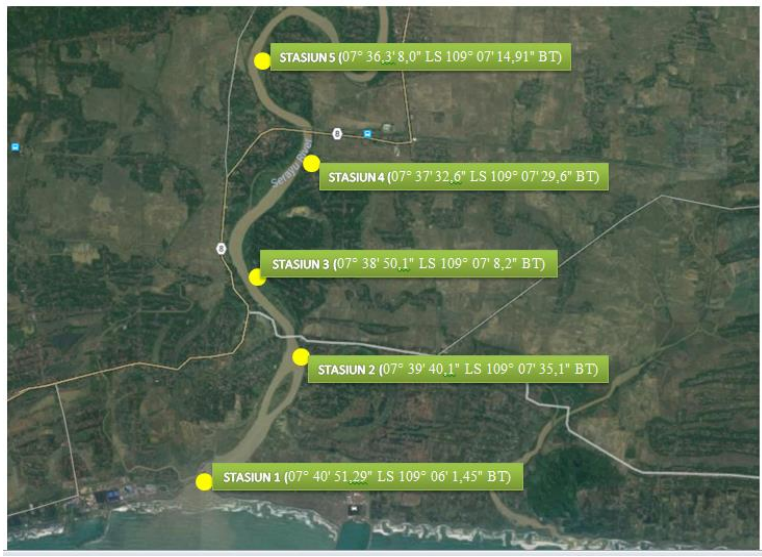

Gambar 1. Lokasi Penelitian

\section{Metode Kerja}

\section{Pengambilan Sampel plankton dan pengukuran produktivitas}

a. Pengambilan sampel plankton diperoleh dengan menyaring menggunakan plankton net nomor 25 (Sachlan, 1982). Identifikasi fitoplankton dan zooplankton dilakukan dengan menggunakan buku Davis (1955) dan Sze (1993). Data hasil identifikasi fitoplankton dan zooplankton dihitung berdasarkan komposisi spesies setiap kelas. Data hasil identifikasi fitoplankton dan zooplankton dihitung dengan rumus kelimpahan menggunakan rumus Sachlan (1982).

b. Pengukuran produktivitas primer dikaji dengan menghitung kekayaan spesies fitoplankton, kelimpahan total fitoplankton (Nybakken (1988), Basmi (2000), dan Nontji (2008)) serta mengukur kandungan klorofil perairan (Geiger \& Osborne, 1992).

c. Pengukuran produktivitas primer dikaji dengan menghitung kekayaan spesies zooplankton dan kelimpahan total zooplankton (Nybakken (1988), Basmi (2000), dan Nontji (2008).

\section{Pengukuran kualitas Sampel Air}

Pengukuran kualitas air (Tabel 1).

\begin{tabular}{|c|c|c|c|}
\hline No. & Parameter & Satuan & Metode/Alat yang digunakan \\
\hline 1 & Kandungan DO & $\mathrm{mg} \cdot \mathrm{L}^{-1}$ & $\mathrm{BSN}, 2004$ \\
\hline 2 & Kandungan Ortofosfat & $\mathrm{mg} \cdot \mathrm{L}^{-1}$ & BSN, 2005 \\
\hline 3 & Kandungan Nitrat & $\mathrm{mg} \cdot \mathrm{L}^{-1}$ & APHA 1992:4005- $-\mathrm{NO}_{3} .4-87$ \\
\hline 4 & $\mathrm{pH}$ & - & $\mathrm{pH}$ Universal \\
\hline 5 & Temperatur & ${ }^{\circ} \mathrm{C}$ & Metode pemuaian dari APHA (1992) \\
\hline 6 & Tingkat Kecerahan & $\mathrm{M}$ & $\begin{array}{l}\text { Metode visualisasi dari APHA } \\
(1992)\end{array}$ \\
\hline 7 & Salinitas & $\%$ & Handreflaktosalinometer \\
\hline 8 & Kekeruhan & NTU & Turbidity \\
\hline
\end{tabular}

\section{Analisis Data}

Kajian produktivitas primer dan sekunder estuari Sungai Serayu dilakukan secara deskriptif dengan membandingkan kekayaan dan kelimpahan fitoplankton dan zooplankton serta kandungan klorofil antarstasiun pengamatan pada saat pasang tertinggi dan surut terendah serta hubungan antara faktor lingkungan dengan produktivitas perairan (produktivitas primer dan produktivitas sekunder) estuari Sungai Serayu dilakukan dengan analisis Prinsiply Component Analys (PCA) menggunakan software PAST.

\section{Hasil dan Pembahasan}

\section{Produktivitas perairan estuari Sungai Serayu}

\section{a. Produktivitas Primer}

Produktivitas primer estuari Sungai Serayu digambarkan dengan hadirnya 23 spesies plankton air tawar, 18 speseis estuary dan 4 spesies plankton laut. Dominasi fitoplankton air tawar di estuary Sungai Serayu diduga karena curah hujan yang tinggi (163-417 mm) diikuti dengan salinitas yang rendah hanya $0-9 \%$.

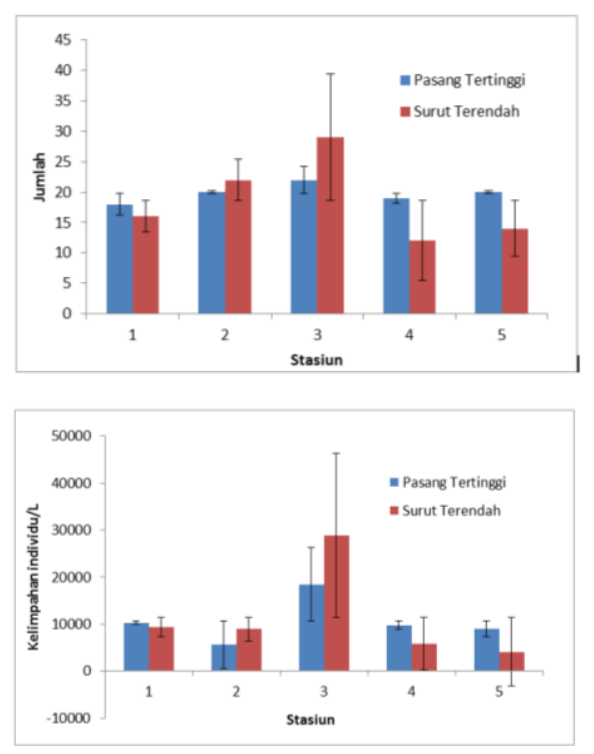

Gambar 2. Histogram Rata-rata Kekayaan dan Kelimpahan Fitoplankton pada 5 Stasiun di Estuari Sungai Serayu $(n=4)$ 
Produktivitas primer juga digambarkan menggunakan kelimpahan fitoplankton. rata-rata kelimpahan fitoplankton disajikan pada Gambar 2 yang menunjukkan bahwa Stasiun 3 memiliki kelimpahan tertinggi pada saat pasang tertinggi (28.875 ind. $\left.\mathrm{L}^{-1}\right)$ maupun surut terendah (18.459 ind. $\left.\mathrm{L}^{-1}\right)$. Jumlah spesies fitoplankton di Stasiun 3 tertinggi pada saat pasang tertinggi maupun surut terendah yaitu 32 spesies dan 35 spesies didominasi oleh Bacillariophyceae.

Bacillariophyceae merupakan spesies yang paling banyak ditemukan selama penelitian pada saat pasang tertinggi maupun surut terendah yaitu 63 spesies dan 61 spesies. Bacillariophyceae merupakan komponen penyusun komunitas plankton maupun bentik di air tawar dan laut
(Davis, 1955; Sze, 1993) serta mampu beradaptasi pada berbagai kondisi lingkungan sehingga dapat hidup pada berbagai tipe habitat yang berbeda dan memiliki sebaran yang luas, seperti air yang bertemperatur dingin, genangan lumpur, tanah basah atau air tawar (Gilbert, 1950).

Bacillariophyceae memiliki peranan penting dalam perikanan khususnya pada rantai makanan (Davis, 1955) dan sebagai plankton yang dikonsumsi oleh ikan air laut dan tawar (Sachlan, 1988). Sebagai produktivitas primer Bacillariophyceae selain dimakan oleh ikan juga dimakan oleh zooplankton, seperti Copepoda, Mycidaeae, dan Euphauceaecea.

Tabel 2. Perbandingan Estuari Sungai Serayu Kelimpahan Fitoplankton di Lokasi Penelitian dan Lokasi Lain

\begin{tabular}{llll}
\hline No & Lokasi & $\begin{array}{l}\text { Kelimpahan } \\
\text { Fitoplankton (ind. }{ }^{-1} \text { ) }\end{array}$ & Referensi \\
\hline 1 & Estuari Sungai Serayu & $4.106-28.875$ & \\
2 & Hilir Sungai Serayu & $1.198-37.135$ & Krismono et al., 2013 \\
3 & Teluk Jakarta & $270.000-1.500 .000$ & Nastiti \& Putri, 2013 \\
4 & Muara Sungai Porong & $18.077-19.200$ & Abida, 2010 \\
5 & Teluk Jakarta & $200-1.704 .000$ & Madubun, 2008 \\
6 & Muara Sungai Sayung Demak & $3.736-6.408$ & Rahmawati et al., 2014 \\
7 & Estuari Sungai Brantas (Porong) & $193-35.243$ & Wulandari, 2009 \\
\hline
\end{tabular}

Tabel 2. terlihat bahwa kelimpahan fitoplankton estuary Sungai Serayu selama penelitian yaitu 4.106-28.875 ind. $\mathrm{L}^{-1}$. Kelimpahan fitoplankton tersebut termasuk stabil dibandingkan hasil penelitian Krismono et al., (2013) yaitu 1.19837.135 ind. $L^{-1}$ begitu juga dengan lokasi lain. Dapat disimpulkan bahwa kelimpahan fitoplankton estuari Sungai Serayu sedang yaitu kelimpahan yang didapatkan tidak melebihi dan kurang dari kelimpahan fitoplankton di lokasi lain, namun bila dibandingkan dengan penelitian Krismono (2013) dari aspek kelimpahan fitoplankton termasuk dalam kategori sedang (tidak melebihi atau kurang dari kelimpahan yang didapatkan selama penelitian).

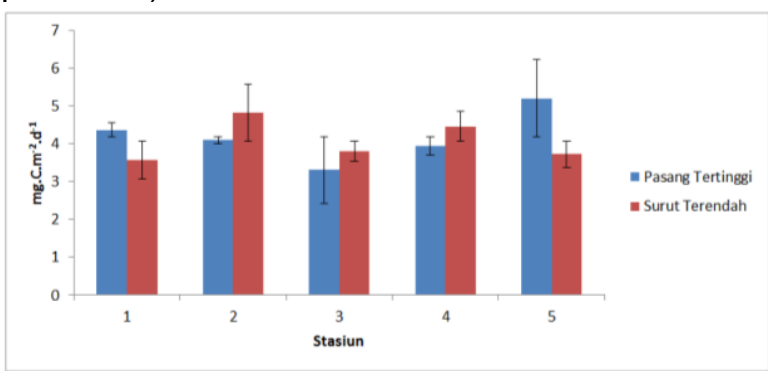

Gambar 3. Histogram Rata-rata Produktivitas Primer Perairan dalam bentuk Karbon pada 5 Stasiun di Estuari Sungai Serayu $(n=4)$
Rata-rata produktivitas primer perairan pada saat pasang tertinggi lebih tinggi $(3,31-5,21$ mg.C. $\left.\mathrm{m}^{-2} \cdot \mathrm{d}^{-1}\right)$ dibandingkan saat surut terendah $\left(3,58-4,83 \mathrm{mg} \cdot \mathrm{C} \cdot \mathrm{m}^{-2} \cdot \mathrm{d}^{-1}\right)$ karena saat surut terendah kekeruhan lebih rendah dibandingkan dengan saat pasang tertinggi (Gambar 3). Perbedaan produktivitas perairan yang terjadi saat surut terendah dibanding pada saat pasang tertinggi karena saat pengambilan pada saat pasang tertinggi terjadi hujan. Kekeruhan yang tinggi akan mempengaruhi penetrasi cahaya sehingga akan berpengaruh terhadap fotosintesis sehingga mengakibatkan penurunan produktivitas primer perairan (Nybakken, 1988). Produktivitas primer perairan di Estuari Sungai Serayu termasuk rendah dibandingkan pengukuran di lokasi lain (Damar, 2003).

Kedua metode pengukuran produktivitas primer yaitu kelimpahan fitoplankton dan produktivitas primer perairan (dalam bentuk karbon) menunjukkan hasil yang berbeda terutama pada stasiun 3, kelimpahan fitoplankton pada Stasiun 3 tidak seiring dengan yang digambarkan dengan metode produktivitas primer perairan dalam bentuk karbon (Gambar 2 dan Gambar 3). Pendekatan dengan menggunakan kelimpahan fitoplankton menunjukkan Stasiun 3 merupakan stasiun yang memiliki kelimpahan tertinggi dan didominasi oleh Bacillariophyceae, tetapi pada produktivitas primer perairan Stasiun 3 merupakan stasiun yang memiliki produktivitas 
primer dalam bentuk karbon terendah. Hal ini sesuai dengan Nybakken (1988) menyatakan bahwa perubahan laju produktivitas primer perairan tidak hanya tergantung pada perubahan jumlah fitoplankton (Bacillariophyceae) tetapi juga oleh proses penurunan jumlah karbon yang dilakukan karena adanya pengikatan karbon (fiksasi) oleh Bacillariophyceae.

\section{b. Produktivitas sekunder}

Produktivitas sekunder pada penelitian ini berdasarkan kekayaan dan kelimpahan zooplankton. Kelimpahan zooplankton selama penelitian pada Gambar 3.

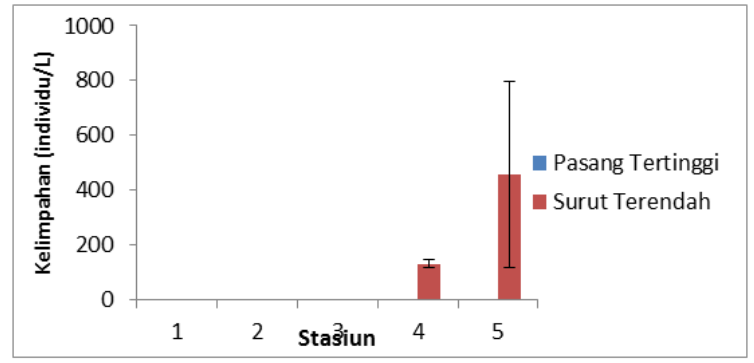

Gambar 4. Histogram Kelimpahan Zooplankton (Produktivitas Sekunder) pada 5 Stasiun di Estuari Sungai Serayu $(\mathrm{n}=4)$

Produktivitas sekunder dilihat dari kelimpahan zooplankton yang didapat selama penelitian sesuai pada Gambar 4. Stasiun 1, 2, dan 3 tidak ditemukan zooplankton sehingga tidak dapat menggambarkan produktivitas primer. Zooplankton pada saat surut terendah di Stasiun 4 (131 ind. $\left.L^{-1}\right)$ dan 5 (458 ind. $\left.L^{-1}\right)$. Spesies zooplankton yang diperoleh didominasi oleh Eucyclops sp. diduga karena salinitas selama penelitian 0-3,5\% (Tseng et al., 2016). Berdasarkan Davis (1955) ; Kennish (1990); (Rice et al., 2014); yaitu kelas Crustacea seringkali mendominasi perairan tawar maupun air laut terutama Subkelas Copepoda. Copepoda berperan penting pada food web di laut yaitu sebagai penghubung antara produktivitas primer dan konsumen tingkat atas dan pemakan fitoplankton, detritus serta zooplankton (Davis, 1955; Nontji, 2008; Rice et al., 2014).

Kelimpahan zooplankton yang mengalami kenaikan dan penurunan di suatu perairan disebabkan oleh beberapa faktor lingkungan seperti salinitas, temperatur, intensitas cahaya, sirkulasi air, ketersediaan makanan, dan predator juga dipengaruhi oleh pertumbuhan, kematian, distribusi dan migrasi serta distribusi yang dipengaruhi oleh parameter fisik-kimiawi seperti (Kennish, 1990; Sumich, 1992). Pranoto (2005) Copepoda (Crustacea) komposisinya lebih tinggi karena umumnya bersifat euryhalin, lebih mampu bertahan dengan perubahan salinitas yang luas, sedangkan kisaran salinitas di perairan muara sungai tersebut antara $9-34 \%$.
Kelimpahan zooplankton estuari Sungai Serayu selama penelitian yaitu $22-156$ ind. $L^{-1}$. Kelimpahan zooplankton tersebut termasuk rendah dibandingkan dengan hasil penelitian Krismono et al., (2013) yaitu $1.006-4.025$ ind. L $^{-1}$ begitu juga dengan penelitian Pranoto et al., (2005) di muara Sungai Serang Yogyakarta yaitu 10.952 - 31.669 ind. $L^{-1}$. Rendahnya kelimpahan zooplankton karena kelimpahan fitoplankton rendah di estuari Sungai Serayu (Basmi, 1999).

\section{Hubungan Faktor Lingkungan dengan Produktivitas Perairan di Estuari Sungai Serayu}

Salah satu faktor lingkungan yang mempengaruhi keberadaan plankton estuari Sungai Serayu salah satunya yaitu salinitas. Faktor lingkungan, produktiktivitas primer, dan produktivitas sekunder yang memberikan kontribusi pada pembentukan komponen 1 dan komponen 2 dijelaskan dan ditampilkan kedalam Gambar 4

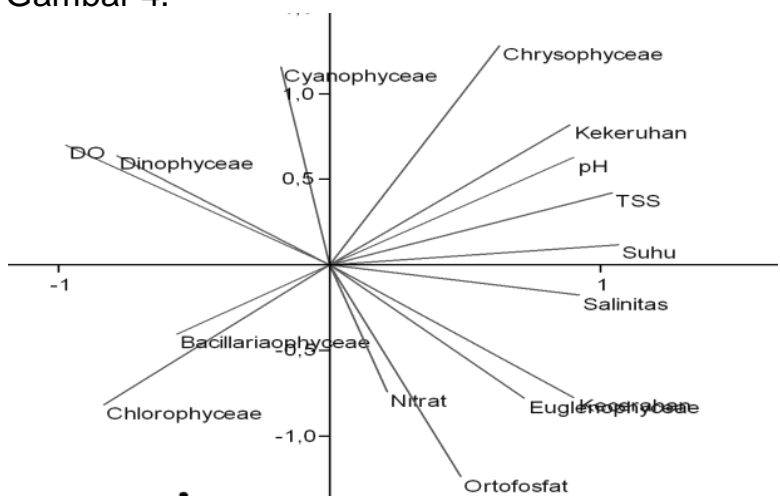

Gambar 5. Biplot antara Divisio Plankton dengan Faktor Lingkungan di Estuari Sungai Serayu pada saat Pasang tertinggi

Hubungan faktor lingkungan di estuari Sungai Serayu digambarkan dengan biplot antara faktor lingkungan dengan kekayaan spesies pada kelima stasiun. Hasil analisis komponen utama pada Gambar 5 memperlihatkan adanya pengaruh yaitu kekeruhan, $\mathrm{pH}$, kandungan TSS, temperatur, tingkat kecerahan, salinitas serta jumlah dan kelimpahan spesies Euglenophyceae dan Chrysophyceae yang berkontribusi dalam membentuk komponen 1 positif. Sebaliknya kandungan DO serta jumlah dan kelimpahan spesies Cyanophyceae, Chlorophyceae, Bacillariophyceae dan Dinophyceae berkontribusi membentuk komponen 1. Jumlah dan kelimpahan spesies Cyanophyceae, Chlorophyceae, Bacillariophyceae dan Dinophyceae di estuari Sungai Serayu lebih dipengaruhi oleh kekeruhan, $\mathrm{pH}$, TSS, temperatur, kecerahan dan salinitas. Ketika kekeruhan, pH, TSS, temperatur meningkat maka diikuti dengan meningkatnya jumlah dan kelimpahan spesies Chrysophyceae tetapi tidak diikuti dengan meningkatnya jumlah dan kelimpahan spesies Bacillariophyceae dan Chlorophyceae. Meningkatnya kekeruhan akan 
diikuti dengan meningkatnya jumlah dan kelimpahan spesies Bacillariophyceae di estuari Sungai Serayu seperti pernyataan Sze (1993). Menurut Sachlan (1982) Bacillariophyceae (Diatome) dapat mengendap di tanah dan membentuk tanah diatome, hal ini terkait run off dan kekeruhan yang tinggi dengan tingginya jumlah dan kelimpahan spesies Bacillariophyceae selama penelitian. Salinitas meningkat, kecerahan, kandungan ortofosfat dan kandungan nitrat maka akan diikuti dengan Euglenophyceae tetapi tidak diikuti dengan meningkatnya jumlah dan kelimpahan spesies Dinophyceae dan Cyanopyceae. Oksigen terlarut meningkat akan diikuti dengan meningkatnya Dinophyceae dan Cyanopyceae.

Loading value tinggi dari data parameter lingkungan saat pasang tertinggi yaitu kekeruhan $(0,81)$, pH $(0,82)$, kandungan TSS $(0,95)$, temperatur $(0,97)$, kecerahan $(0,82)$, salinitas $(0,84)$ dan kandungan oksigen terlarut $(-0,89)$. Hasil tersebut mengindikasikan pengaruh dari masukan air laut terhadap faktor lingkungan estuari Sungai Serayu. Pengaruh faktor lingkungan terhadap produktivitas primer terlihat pada perubahan kekayaan dan kelimpahan fitoplankton yaitu Chlorophyceae $(0,7)$ dan Dinophyceae $(0,7)$.

Faktor lingkungan, produktiktivitas primer dan produktivitas sekunder memberikan kontribusi pada pembentukan komponen 1 dan komponen 2 digambarkan dan ditampilkan kedalam Gambar 5.

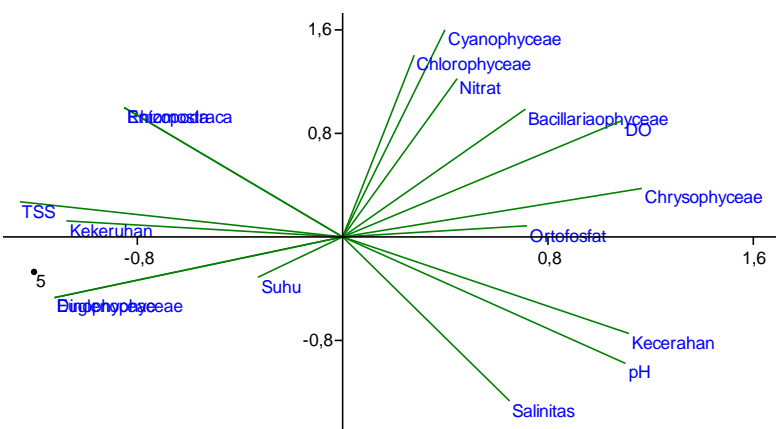

Gambar 6. Biplot antara Divisio Plankton dengan Faktor Lingkungan di Estuari Sungai Serayu pada saat Surut Terendah

Hasil analisis komponen utama pada Gambar 6 memperlihatkan adanya korelasi positif antara kandungan ortofosfat, $\mathrm{pH}$, kecerahan, kandungan DO dengan jumlah dan kelimpahan spesies Bacillariophyceae dan Chrysophyceae yang berkontribusi dalam membentuk komponen 1 positif. Sebaliknya kandungan TSS, kekeruhan, serta jumlah dan kelimpahan spesies Entomostraca, Rhizopoda, Euglenophyceae dan Dinophyceae berkontribusi membentuk komponen 1 negatif. Berbeda pada saat pasang tertinggi, pada saat surut terendah jumlah dan kelimpahan spesies Bacillariophyceae dan Chrysophyceae lebih dipengaruhi oleh kandungan ortofosfat, $\mathrm{pH}$, kecerahan dan DO. Sedangkan jumlah dan kelimpahan spesies Entomostraca, Rhizopoda, Euglenophyceae dan Dinophyceae dipengaruhi oleh TSS dan kekeruhan.

Kandungan nitrat, kandungan oksigen terlarut dan kandungan ortofosfat yang meningkat akan diikuti meningkatnya jumlah dan kelimpahan spesies Bacillariophyceae, Chrysophyceae, Chlorophyceae dan Cyanophyceae tetapi tidak diikuti dengan meningkat jumlah dan kelimpahan spesies Dinophyceae dan Euglenophyceae. Temperatur yang meningkat diikuti dengan meningkat jumlah dan kelimpahan spesies Dinophyceae dan Euglenophyceae. Nontji (2008) menyatakan bahwa distribusi Bacillariophyceae dipengaruhi oleh faktor lingkungan yaitu temperatur, salinitas dan arus. Disamping temperatur dan salinitas kecerahan (intensitas cahaya) juga sangat berpengaruh besar terhadap laju distribusi spasial fitoplankton. Kecerahan, $\mathrm{pH}$ dan salinitas yang meningkat tidak diikuti dengan meningkat jumlah dan kelimpahan spesies Rhizopoda dan Entomostraca. Meningkat jumlah dan kelimpahan spesies Rhizopoda dan Entomostraca apabila TSS dan kekeruhan meningkat. Selama penelitian spesies Rhizopoda dan Entomostraca yang didapat selama penelitian merupakan spesies perairan tawar sehingga apabila salinitas naik komposisi dan kelimpahan zooplankton akan berkurang.

Loading value tinggi dari data parameter lingkungan pada surut terendah yaitu $\mathrm{pH}(0,80)$, kandungan TSS $(-0,91)$, dan kecerahan $(0,81)$. Hasil tersebut mengindikasikan pengaruh saat pengambilan sampel yang dilakukan pada sore hari, sehingga kandungan TSS, $\mathrm{pH}$, dan kecerahan mempengaruhi kekayaan spesies suatu lokasi. Tingginya kandungan TSS mengindikasikan banyaknya freshwater dibandingkan air laut. Hal tersebut tergambarkan pada kekayaan spesies yang didapatkan saat surut terendah yaitu spesies freshwater. Pengaruh faktor lingkungan terhadap produktivitas primer terlihat pada perubahan komposisi dan kelimpahan fitoplankton yaitu Chrysophyceae $(0,8)$, Euglenophyceae $(0,8)$, dan Dinophyceae $(0,8)$.

Berdasarkan hasil masing-masing PCA dari data saat pasang tertinggi dan surut terendah dengan loading value tertinggi pada saat pasang tertinggi dan surut terendah yaitu $\mathrm{pH}(0,8)$, TSS $(0,9)$ dan kecerahan $(0,8)$. Pengaruh oleh $\mathrm{pH}$, kandungan TSS dan tingkat kecerahan terhadap produktivitas primer dan sekunder (Parsons et al., 1977; Sachlan, 1982).

Pengaruh tingkat kecerahan pada produktivitas primer maupun sekunder tergambar dari oksigen dan glukosa hasil fotosintesis. Tingkat kecerahan estuari Sungai Serayu selama penelitian sebesar 0,05-0,59 $\mathrm{m}$, hasil tersebut 
menunjukkan intensitas cahaya di lokasi ini rendah. Rendahnya tingkat kecerahan diikuti dengan tingginya kekeruhan dan TSS yaitu 10391 NTU dan 144-193 mg. ${ }^{-1}$. Kedua parameter tersebut berpengaruh pada rendahnya produktivitas primer perairan estuari Sungai Serayu yaitu sebesar $0,58-13,78 \mathrm{mg} \cdot \mathrm{C} \cdot \mathrm{m}^{-2} \cdot \mathrm{d}^{-1}$. Produktivitas primer perairan tersebut juga termasuk rendah dibandingkan dengan penelitian yang sudah dilakukan di lokasi lainnya (Alianto et al., 2008; Damar, 2012).

\section{Daftar Referensi}

Abida, I.W. 2010. Struktur Komunitas dan Kelimpahan Fitoplankton di Perairan Muara Sungai Porong Sidoarjo. Jurnal Kelautan. 3(1): 36-40.

Afdal. 2011. Pertukaran Gas $\mathrm{CO}_{2}$ Udara-Laut di Perairan Pesisir: Studi Kasus di Selat Nasik, Belitung dan Estuari Donan, Cilacap. Tesis. Program Pascasarjana. Institut Pertanian Bogor, Bogor.

Alaerts, G.A. \& Santika, S.S. 1987. Metode Penelitian Air. Usaha Nasional, Surabaya.

Alianto., Adiwilaga, E. M., \& A, Damar. 2008. Produktivitas Primer Fitoplankton Kaitannya Dengan Unsur Hara dan Cahaya Di Perairan Teluk Banten. Indonesian Journal Of Aquatic Sciences And Fisheries. 15(1): 21-26.

APHA, AWWA and WEF. 1992. Standart Method for the Examination of Water and Wastewater. American Public Health Association, American Water Works Association, and Water Environment Federation, Washington.

Basmi. H.J. 1999. Planktonologi : Bioekologi Plankton Algae. Fakultas Perikanan dan IImu Kelautan. Institut Pertanian Bogor, Bogor.

BSN. 2004. Standar Nasional Indonesia (SNI). Badan Standarisasi Nasional (BSN), Jakarta.

2005. Standar Nasional Indonesia (SNI). Badan Standarisasi Nasional (BSN), Jakarta.

Damar, A. 2003. Effects of Enrichment on Nutrien Dynamics, Phytoplankton Dynamics and Productivity in Indonesian Tropical Waters : A Comparison between Jakarta Bay, Lampung Bay and Semangka Bay. Dissertation. Der MathematischNaturwissenschaftlichen Fakultät. der Christian-Albrechts-Universität. zu Kiel

\section{Simpulan}

Perairan estuari Sungai Serayu dinilai kurang prospek untuk perikanan berdasarkan produktivitas primer dan produktivitas sekunder. Hubungan positif antara faktor lingkungan dengan kekayaan dan kelimpahan plankton (produktivitas primer dan produktivitas sekunder) pada saat pasang tertinggi dan surut terendah yaitu tingkat kecerahan, kandungan TSS, dan $\mathrm{pH}$.

. 2012. Net Phytoplankton Community Structure And Its Biomass Dynamic In The Brantas River Estuari, Java, Indonesia. Coastal Environments: Focus On Asian Coastal Regions. DOI 10.1007/978-90-481-3002-3

Davis, C.C. 1955. The Marine And Freshwater Plankton. Michigan State University Press, Chicago.

Geiger, H. J., \& B. A. Osborne. 1992. Algal photosynthesis. Routledge, Chapman and Hall, Inc. New York. Page 107-121.

Gilbert, S.M. 1950. The Fresh Water Algae Of The United State. New York: MC Graw-Hill Book Company, INC.

Kementerian Kehutanan RI. 2016. BPDAS Serayu Opak Progo, Luas DAS. http://bpdasserayuopakprogo. Diakses pada 3 Januari 2017

Kennish, M.J. 1992. Ecology of Estuaries : Anthtopogenic Effects. Marine Science Series, Inc. Florida.

Krismono, Hedianto, D. A., Zahid, A., \& Rahardjo, M. F. 2013. Biolimnologi Sungai Serayu Sebagai Dasar Pengelolaan. Prosiding Forum Nasional Pemulihan dan Konservasi Sumberdaya Ikan - IV.

Madubun, U. 2008. Produktivitas Primer Fitoplankton Dan Kaitannya Dengan Unsur Hara Dan Cahaya Di Perairan Muara Jaya Teluk Jakarta. Tesis. Program Pascasarjana, Institut Pertanian Bogor, Bogor.

Nastiti, A.S., \& Putri, M.R. 2013. Komposisi dan Kelimpahan Fitoplankton di Teluk Jakarta. Oseanologi dan Limnologi di Indonesia. 39(2): 125-138.

Nontji, A. 2008. Plankton Laut. Lembaga IImu Pengetahuan Indonesia. LIPI Press, Jakarta.

Nybakken, J. W. 1988. Biologi Laut, Suatu Pendekatan Ekologis. Alih Bahasa H. M. Eidman, Koesoebiono, D. G. Bengen, M. 
Hutomo, S. Sukarjo. PT. Gramedia, Jakarta.

Parsons, T. R., M. Takeshi, \& B. Hagrave. 1977. Biological Oceanographic Proscsses. Third edition. Oxford. Pergamon press. Great Britain.

Pranoto, B.A., Ambariyanto., \& Zainuri. M. 2005. Struktur Komunitas Zooplankton di Muara Sungai Serang, Jogjakarta. IImu Kelautan. 10(2): $90-97$.

Rahmawati, I., Hendrarto, I. B., \& Purnomo, P.W., 2014. Fluktuasi Bahan Organik dan Sebaran Nutrien serta Kelimpahan Fitoplankton dan Klorofil-A di Muara Sungai Sayung Demak. Diponegoro Journal Of Maquares. 3(1): 27-36.

Rice, E., Dam, H.G., \& Stewart, G. 2014. Impact of Climate Change on Estuarine Zooplankton: Surface Water Warming in Long Island Sound is Associated with Changes in Copepod Size and Community Structure. Springer. DOI 10.1007/s12237-014-9770-0

Sachlan, N. 1982. Planktonologi. Corresponden Course Centre. Direktorat Jenderal Perikanan, Jakarta.

Sumich, J.L. 1992. An Introduction to The Biology of Marine Life Fifth Edition. WCB WM. C. Brown Publisher. United States of American, 2460 Kerper Bouleverd Dubuqua IA. 52001.

Sverdrup, K. A., Alyn, C.D \& Alison, B.D. 2008. An Introduction to the World's Oceans. $10^{\text {th }}$ ed.p.cm. McGraw-Hill Global Education Holdings, LLC.

Sze, P. 1993. A Biology of the Algae. Second Edition.Wm. C. Bown Publishers, Dubuque.

Tseng, L.C., Hsiao, S.H., Sarkar, S.K., Bhattacharya, B.D., Hen, Q.C., \& Hwang, J.S. 2016. Influence of Kuroshio Water on the Annual Copepod Community Structure in an Estuari in the North West Pacific Ocean. Continental Shelf Research. 118: 165-176.

Wulandari, D. 2009. Keterikatan antara Kelimpahan Fitoplankton dengan Parameter Fisika Kimia di Estuari Sungai Brantas (Porong), Jawa Timur. Skripsi. Fakultas Perikanan dan IImu Kelautan. Institut Pertanian Bogor, Bogor. 